\title{
PENGARUH PELATIHAN KERJA DAN STRES KERJA TERHADAP PRODUKTIVITAS KERJA KARYAWAN BAGIAN PRODUKSI DEPARTEMEN R-PET PT. NAMASINDO PLAS BANDUNG BARAT
}

\author{
Wandy Zulkarnaen ${ }^{1}$; Abin Suarsa ${ }^{2}$; Rachmat Kusmana ${ }^{3}$ \\ STIE Muhammadiyah Bandung \\ J1. Karapitan No.143 Bandung \\ Email: wandy.zulkarnaen@stiemb.ac.id ${ }^{1,3}$ abinsuarsa@ stiemb.ac.id ${ }^{2}$
}

\begin{abstract}
Abstrak
Penelitian ini bertujuan untuk mengetahui Pengaruh Pelatihan Kerja dan Stres Kerja Terhadap Produktivitas Kerja Karyawan Bagian Produksi Departemen R-PET di PT Namasindo Plas Bandung Barat. Latar belakang penelitian ini berkaitan dengan tidak tercapainya target produksi selama tiga tahun berturut turut dari tahun 2014 hingga 2016 yang ada di bagian produksi yaitu pada manajemen Bagian Produksi Departemen R-PET di PT. Namasindo Plas. Metode yang digunakan dalam penelitian ini adalah metode deskriptif dan verifikatif dengan pendekatan kuantitatif. Populasi penelitian adalah semua karyawan/i Bagian Produksi Departemen R-PET PT Namasindo Plas Bandung Barat yaitu sebanyak 90 orang dengan jumlah sample dengan menggunakan teknik Slovin sebanyak 74 orang. Hasil penelitian menunjukan bahwa Pelatihan dan stress kerja memberikan pengaruh sebesar $87,5 \%$ terhadap produktivitas kerja, angka 87,5\% disini artinya setiap perubahan produktivitas kerja sebesar $87,5 \%$ dipengaruhi oleh perubahan variabel Pelatihan dan Stress Kerja. Adapun sisanya sebesar $12,5 \%$ disebabkan oleh variabel-variabel lain diluar kedua variabel tersebut yang tidak dilibatkan dalam penelitian ini, antara lain motivasi, imbalan.
\end{abstract}

Kata kunci: Pelatihan Kerja, Stres Kerja, Produktivitas Kerja

\section{PENDAHULUAN}

Tujuan utama yang diharapkan oleh seluruh perusahaan dalam kegiatan usahanya adalah mencapai laba atau nilai yang optimal dengan menggunakan sumber daya manusia secara efektif dan efisien untuk kelangsungan hidup perusahaan. Dalam usaha pencapaian tujuan perusahaan, pihak-pihak yang terlibat paling dominan adalah pihak karyawan selaku pelaksana, pihak manajemen dan para pemegang saham. Sumber daya manusia merupakan asset organisasi yang sangat vital karena itu keberadaannya dalam perusahaan tidak tergantikan oleh sumber daya lainnya.

Dalam mencapai tujuan perusahaan tersebut, pihak manajemen berusaha mempertahankan keberhasilan yang sudah dicapai dan 
mengevaluasi kekurangan dengan berkelanjutan dengan melihat kekuatan dan kelemahan yang terdapat dalam perusahaan serta menjalankan kebijakan perusahaan dengan baik dan tepat. Kebijaksanaan tersebut meliputi Manajemen Perencanaan Sumber daya Manusia dimana dilakukan secara integrasi dan bertujuan untuk meningkatkan performance seluruh sumber daya manusia.

Tiga fungsi yang harus dijalankan dalam memenangkan persaingan global yaitu membangun kemampuan strategik, memperluas ikatan, mengelola peran baru.

Di era persaingan global yang semakin ketat, peran pelatihan kerja dan pengelolaan stress kerja menjadi semakin penting untuk menghasilkan sumber daya manusia produktif, kreatif, inovatif, dan profesional. Pelatihan kerja dan stres kerja merupakan salah satu langkah strategik untuk meningkatkan mutu kinerja sumber daya manusia agar mampu merespon tantangan dunia bisnis, khususnya melalui peningkatan produktivitas individu dan kelompok .

\section{Dalam} pelaksanaan memperluas ikatan manajemen sumber daya manusia menggunakan keahliannya untuk membantu organisasi mempengaruhi perilaku suppliers, distributor dan individuindividu lain untuk mengatur kegiatan internal perusahaan, agar membuahkan hasil maksimal. Difungsi ketiga Manajemen sumber daya manusia berkewajiban untuk mendapatkan calon tenaga kerja yang benar-benar mempunyai kompetensi, mengembangkan manajemen kinerja profesional, dan sistem kompensasi yang menarik, sehingga memotivasi penampilan perilaku pegawai yang selaras dengan harapan perusahaan dalam rangka mengisi perubahan kebutuhan perusahaan akan tenaga kerja.

PT. Namasindo Plas beralamat di jalan Raya Cangkorah Kp. Cangkorah RT. 02 RW. 01 Batujajar Kabupaten Bandung adalah perusahaan pelopor pertama yang menggunakan bahan recycle plastic bahan PET dan Bagian Produksi Departemen R-PET beroperasi bulan April tahun 2008 sebagai CSR (Corporate Social Responsibility) PT. Namasindo Plas dimana merupakan suatu kegiatan tanggung jawab sosial dari sebuah perusahaan kepada masyarakat dan lingkungan hidup atas imbas dari 
kegiatan-kegiatan usahanya, berdasar dari pedoman ISO 26000 sebagai pedoman tanggung jawab sosial perusahaan.

Departemen Recycle Polythelyene Terepthalate (R-PET) menghasilkan produk bahan baku bagi industry AMDK diproyeksi untuk mendukung program Go Green PT. Danone Aqua yang menjadi leader market produk air minum dan kemasan di Indonesia.

Penggunaan teknologi terbaru dilakukan yang mana bertujuan untuk menghasilkan kualitas dan kuantitas juga presisi dari produk yang dihasilkan sehingga terjaga hubungan kuat dengan pelanggan karena majunya sebuah perusahaan adalah dapatnya memberikan kepuasan produk oleh pelanggan.

Departemen R-PET sebagai anak perusahaan PT. Namasindo plas tidak lepas dari permasalahan lingkungan internal dan lingkungan eksternal karena akan mempengaruhi cara kerja karyawan dalam bekerja, masalah yang sangat berkaitan erat dalam mengurangi tekanan yang dialami karyawan dalam pemenuhan persepsi dan nilai kenyamanan karyawan yang dapat menyebabkan tinggi rendahnya produktivitas kerja karyawan di suatu organisasi dimana harus lebih baik lagi dalam analisa SWOT nya terutama dibagian SDM yang harus terus berkelanjutan untuk mempertahankan dan memajukan visi dan misi perusahaan.

Berkaitan yang dihadapi Bagian Produksi Departemen R-PET di PT. Namasindo Plas adalah tidak tercapainya target produksi selama tiga tahun berturut turut yang menjadi target yang diberikan manajemen.

Berikut data yang ditampilkan dimana pencapaian target per tahunnya tidak tercapai dari 2014 s/d 2016.

Tabel 1. Data Pencapaian Produksi Bagian Produksi Departemen R-PET PT. Namasindo Plas Bandung Barat Tahun 2014 s/d 2016

\begin{tabular}{|c|c|c|c|c|c|}
\hline Mesin & Jenis Produk & $\begin{array}{c}\text { Target } \\
\text { Output }\end{array}$ & $\begin{array}{c}\text { Average } \\
\text { Target } \\
(2014)\end{array}$ & $\begin{array}{c}\text { Average } \\
\text { Target } \\
(2015)\end{array}$ & $\begin{array}{c}\text { Average } \\
\text { Target } \\
(2016)\end{array}$ \\
\hline Sorema 1 & Cuci flakes & $85 \%$ & $47 \%$ & $0 \%$ & $17 \%$ \\
\hline Sorema 2 & Cuci flakes & $85 \%$ & $89 \%$ & $100 \%$ & $88 \%$ \\
\hline Erema 1 & Pellet & $85 \%$ & $68 \%$ & $41 \%$ & $49 \%$ \\
\hline
\end{tabular}




\begin{tabular}{|c|c|c|c|c|c|}
\hline Erema 2 & Pellet & $85 \%$ & $89 \%$ & $100 \%$ & $92 \%$ \\
\hline Buhler & Pellet & $85 \%$ & $84 \%$ & $100 \%$ & $80 \%$ \\
\hline & $\begin{array}{c}\text { Average All } \\
\text { Mesin }\end{array}$ & $85 \%$ & $75,4 \%$ & $68.2 \%$ & $65.2 \%$ \\
\hline
\end{tabular}

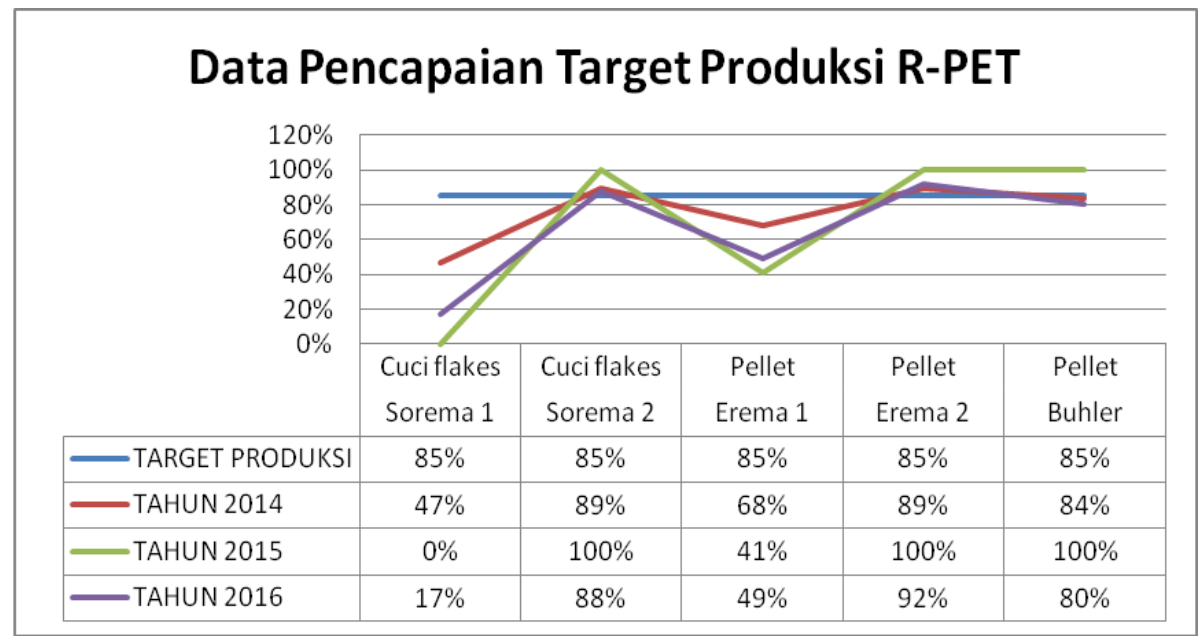

Sumber : data produksi departemen R-PET,2018

Gambar 1. Grafik Pencapaian Target Produksi Bagian Produksi Departemen R-PET PT. Namasindo Plas Bandung Barat Tahun 2014 s/d 2016

Berdasarkan tabel di atas semua dihadapkan untuk mempertahankan mesin harus produktifitasnya terjaga agar distribusi hasil produksi tetap dikarenakan alur proses merupakan terjaga. Faktor kerusakan mesin dan satu rangkaian bilamana salah satu pengendalian mesin menjadi faktor mesin tidak tercapai target maka yang sering terjadi didepartemen produktivitas tidak tercapai. Dan selama 2014 sampai 2016 hasil belum produksi dimana ada aspek yang stabil. Sasaran utama manajemen sumber daya manusia adalah menciptakan sistem pemberdayaan personil yang dapat menampilkan kinerja produktif.

Produktivitas kerja merupakan kemampuan pegawai dalam mencapai hasil (output), terutama dilihat dari sisi kuantitasnya. Kondisi sekarang dipengaruhi oleh SDM terutama dari pola wawasan setting mesin dan penanganan kerusakan mesin.

Berkaitan yang dihadapi Bagian Produksi Departemen R-PET di PT. Namasindo Plas adalah tidak tercapainya target produksi selama tiga tahun berturut turut yang menjadi target yang diberikan manajemen. Dari kondisi tersebut perlu adanya pelatihan 
kerja yang diberikan adalah pelatihan hardskill dimana penguasaan ilmu pengetahuan, teknologi dan keterampilan yang berhubungan dengan kebutuhan untuk meningkatkan produktivitas kerja karyawan di Bagian Produksi Departemen R-PET baik secara kualitas dan kuantitas.. Tahun 2014, 2015 dan 2016 Departemen HRD terus memberikan pelatihan yang berkenaan mengenai kualitas kerja secara hardskill dan softskill juga kualitas produk. Pelatihan kerja dilakukan untuk mewujudkan tenaga kerja profesional dan produktif, untuk itu diperlukan keterampilan yang sesuai dengan bidang tugasnya. Hal ini membuat manajemen semakin sadar bahwa perusahaan tidak bisa lepas dari lingkungannya yang selalu berubah setiap saat.

Berikut data pelaksanaan pelatihan kerja yang diberikan HRD PT. Namasindo Plas tahun 2014 s/d 2016.

Tabel 2. Pelatihan HRD Bagian Produksi Departemen R-PET PT. Namasindo Plas Bandung Barat Tahun 2014

\begin{tabular}{|c|c|c|c|}
\hline $\begin{array}{c}\text { Jadwal } \\
\text { Pelatihan }\end{array}$ & $\begin{array}{c}\text { Nama } \\
\text { Pelatihan }\end{array}$ & $\begin{array}{c}\text { Kehadiran } \\
\text { Pelatihan }\end{array}$ & Peserta \\
\hline $\begin{array}{c}\text { Januari s/d } \\
\text { Desember } \\
2014\end{array}$ & $\begin{array}{c}\text { Sistem } \\
\text { Oracle }\end{array}$ & $50 \%$ & Staff \\
\hline
\end{tabular}

Sumber : HRD PT. Namasindo Plas, 2018

Tabel 3. Pelatihan HRD Bagian Produksi Departemen R-PET PT. Namasindo Plas Bandung Barat Tahun 2015

\begin{tabular}{|l|c|c|c|}
\hline \multicolumn{1}{|c|}{ Jadwal Pelatihan } & Nama Pelatihan & $\begin{array}{c}\text { Kehadiran } \\
\text { Pelatihan }\end{array}$ & Keterangan \\
\hline 10 Januari 2015 & FSSC & $100 \%$ & Non Staff + Staff \\
\hline 8 Pebruari 2015 & Buiding Motivation & $50 \%$ & Staff \\
\hline Maret 2015 & Refresing Job Desk & $100 \%$ & Non Staff + Staff \\
\hline 28 s/d 30 Juli 2015 & TPM & $50 \%$ & Staff \\
\hline 8 s/d 9 Desember 2015 & Quality for All & $100 \%$ & Non Staff + Staff \\
\hline 10 Desember 2015 & ABC Sistem & $100 \%$ & Non Staff + Staff \\
\hline
\end{tabular}

Sumber : HRD PT. Namasindo Plas, 2018

Tabel 4. Pelatihan HRD Bagian Produksi Departemen R-PET PT. Namasindo Plas Bandung Barat Tahun 2016

\begin{tabular}{|c|c|c|c|}
\hline Jadwal Pelatihan & Nama Pelatihan & $\begin{array}{c}\text { Kehadiran } \\
\text { Pelatihan }\end{array}$ & Keterangan \\
\hline 18 Januari 2016 & FSSC & $100 \%$ & Non staff+ Staff \\
\hline 25 Pebruari 2016 & Refresing Job Desk & $100 \%$ & Non staff+ Staff \\
\hline 10 November 2016 & Quality Manajemen Sistem & $50 \%$ & Staff \\
\hline $\begin{array}{c}\text { 16-17 November } \\
2016\end{array}$ & Leadership & $50 \%$ & Staff \\
\hline 21 November 2016 & Sertifikat Halal & $100 \%$ & Non staff+ Staff \\
\hline 28 November 2016 & Boiler & $5 \%$ & Staff \\
\hline
\end{tabular}


Sumber : HRD PT. Namasindo Plas, 2018

Stress kerja yang dialami karyawan di Bagian Produksi karyawan dalam organisasi bilamana Departemen R-PET. Produktivitas proses penyelesaian pekerjaan di yang meningkat tentu akan pengaruhi gangguan baik fisik maupun mempengaruhi mental, kemampuan mental. Salah satu penyebab stress kerja adalah beban kerja, dan diBagian dan fisik para karyawan serta hubungan antara atasan dan bawahan Produksi Departemen R-PET dari juga lingkungan kerja tentu berpotensi tahun ke tahun target produktivitas mesinnya hampir semuanya naik dan bisa dilihat dari table berikut.

Tabel 5. Target per Tahun Bagian

Produksi Departemen R-PET PT.

Namasindo Plas Bandung Barat Barat

\begin{tabular}{|c|c|c|c|c|}
\hline Mesin & $\begin{array}{c}\text { Jenis } \\
\text { Produk }\end{array}$ & $\begin{array}{c}\text { Target } \\
\text { perhari } \\
(2014)\end{array}$ & $\begin{array}{c}\text { Target } \\
\text { perhari } \\
(2015)\end{array}$ & $\begin{array}{l}\text { Target } \\
\text { perhari } \\
(2016)\end{array}$ \\
\hline $\begin{array}{c}\text { Sorema } \\
1\end{array}$ & $\begin{array}{c}\text { Cuci } \\
\text { flakes }\end{array}$ & 15 ton & 16 ton & 18 ton \\
\hline $\begin{array}{c}\text { Sorema } \\
2\end{array}$ & $\begin{array}{c}\text { Cuci } \\
\text { flakes }\end{array}$ & 27 ton & 30 ton & 33 ton \\
\hline $\begin{array}{c}\text { Erema } \\
1\end{array}$ & Pellet & 9 ton & 10 ton & 10 ton \\
\hline $\begin{array}{c}\text { Erema } \\
2\end{array}$ & Pellet & 24 ton & 27 ton & 28 ton \\
\hline Buhler & Pellet & 30 ton & 30 ton & 31 ton \\
\hline
\end{tabular}

mengalami tekanan pekerjaan yang menyebabkan stres pada individu tersebut.

Perusahaan berusaha mengelola stres kerja dengan melakukan perbaikan penggajian sesuai UMR sejak tahun 2014 ditambah aturan lemburan lebih 4 jam diberi kalori tambahan, juga diberikan jaminan Kesehatan dan Jaminan Hari Tua. Gathering di alam terbuka untuk meningkatkan kerjasama antar karyawan dan hari

Kebijakan Manajemen yang per ulang tahun perusahaan dirayakan tahunnya menaikan target produktivitas bersama dengan acara seni dan olah tentu akan menjadi beban dan raga dimana ada pembagian door prize berpotensi stres bertambah bagi para juga ada perayaan keagamaan.

Tabel 6. Data Pra-Survey Stres Kerja Karyawan Bagian Produksi Departemen RPET PT. Namasindo Plas Bandung Barat Barat

\begin{tabular}{|l|l|c|c|c|c|c|c|}
\hline \multirow{2}{*}{ No } & \multicolumn{1}{|c|}{ Pernyataan } & $\mathbf{5}$ & $\mathbf{4}$ & $\mathbf{3}$ & $\mathbf{2}$ & $\mathbf{1}$ & \multirow{2}{*}{ JML } \\
\cline { 3 - 7 } & \multicolumn{1}{|c|}{ SS } & $\mathbf{S}$ & $\mathbf{C S}$ & $\mathbf{T S}$ & $\mathbf{S T S}$ & \\
\hline 1 & $\begin{array}{l}\text { Saya merasakan berat bekerja di } \\
\text { departemen produksi }\end{array}$ & 7 & 7 & 3 & 12 & 21 & 50 \\
\hline 3 & $\begin{array}{l}\text { Saya rasakan lingkungan kerja panas } \\
\text { dan lembab diarea produksi }\end{array}$ & 13 & 2 & 5 & 7 & 23 & 50 \\
\hline $\begin{array}{l}\text { Saya lihat masih terjadi konflik kerja } \\
\text { baik internal maupun antar } \\
\text { departemen di produksi }\end{array}$ & 10 & 0 & 5 & 21 & 14 & 50 \\
\hline
\end{tabular}




\begin{tabular}{|l|l|c|c|c|c|c|c|}
\hline 4 & $\begin{array}{l}\text { Saya lihat masih longgar pengawasan } \\
\text { terhadap antar personel dilapangan }\end{array}$ & 8 & 4 & 7 & 12 & 19 & 50 \\
\hline 5 & $\begin{array}{l}\text { Saya rasakan masih ada otoritas kerja } \\
\text { banyak yang tidak jalan }\end{array}$ & 6 & 10 & 18 & 9 & 7 & 50 \\
\hline Jumlah & 44 & 23 & 38 & 61 & 84 & \\
\hline Skor & 44 & 46 & 114 & 244 & 420 & 868 \\
\hline \multicolumn{2}{|c|}{ Persentasi (\%) } & 5.1 & 5,3 & 13,1 & 28,1 & 48,4 & 100 \\
\hline
\end{tabular}

Sumber : Data olahan, 2018

Berdasakan data pra-survey semakin tinggi pengetahuan dan tentang stres kerja, maka data pra- wawasan juga daya analisa terhadap survey paling tinggi nilainya pada permasalahan permasalahan yang Sangat Tidak Setuju (STS) sebanyak dihadapinya. Oleh karena itu dalam $48.4 \%$ dan pra-survey yang paling melakukan penulisan tentang pengaruh sedikit nilainya Sangat Setuju (SS) pelatihan terhadap produktivitas kerja sebanyak $5.1 \%$ diperlukan penelitian.

Perusahaan dapat hidup survival dengan cara semaksimal KAJIAN LITERATUR DAN mungkin berusaha mengatasi tantangan-tantangan dari lingkungan kerja yang komplek, maka konsekuensinya perusahaan akan selalu menghadapi perubahan diinternal dan diluar lingkungan perusahaan. Oleh karena itu pimpinan manajemen dan para pemegang saham semakin menyadari bahwa pelatihan sangat penting merupakan salah satu proses yang berkesinambungan untuk dapat meningkatkan produktivitas kerja yang efektif dan efisien.

Keberhasilan tujuan perusahaan tergantung dari peningkatan produktivitas kerja yang mana berkaitan erat dengan kualitas pelatihan para karyawan sehingga akan

\section{HIPOTESIS}

\section{Pelatihan Kerja}

Pada umumnya setiap organisasi sering terjadi suatu kesenjangan antara kebutuhan akan promosi tenaga kerja yang diharapkan oleh organisasi dengan kemampuan tenaga kerja dalam merespon kebutuhan, organisasi perlu melakukan suatu upaya untuk menjembatani kesenjangan ini. Salah satu cara yang dapat dilakukan organisasi adalah melalui program pelatihan. Melalui program pelatihan diharapkan seluruh potensi yang dimiliki dapat ditingkatkan sesuai dengan keinginan organisasi atau setidaknya mendekati apa yang diharapkan oleh organisasi. 
Berikut penjelasan beberapa ahli mengenai pengertian pelatihan Menurut Mangkunegara (2013:44):

Pelatihan adalah suatu proses pendidikan jangka pendek yang menggunakan prosedur sistematis dan terorganisir dimana pegawai non manajerial pelajari pengetahuan dan keterampilan teknis dalam tujuan terbatas.

Pelatihan merupakan proses memberikan atau meningkatkan kemampuan dan keterampilan serta menanamkan atau menyesuaikan sikap kepada karyawan atau proses membantu karyawan untuk mengkoreksi kekurangan-kekurangan dalam kinerjanya di masa silam (Yuniarsih 2016:134).

\section{Dimensi pelatihan kerja} menurut Mangkunegara (2013:44) : a)
Tujuan
Pelatihan;
b) Materi;

Metode;

d) Kualifikasi

Peserta;

e)

Kualifikasi Pelatih; f) Waktu (Banyaknya sesi).

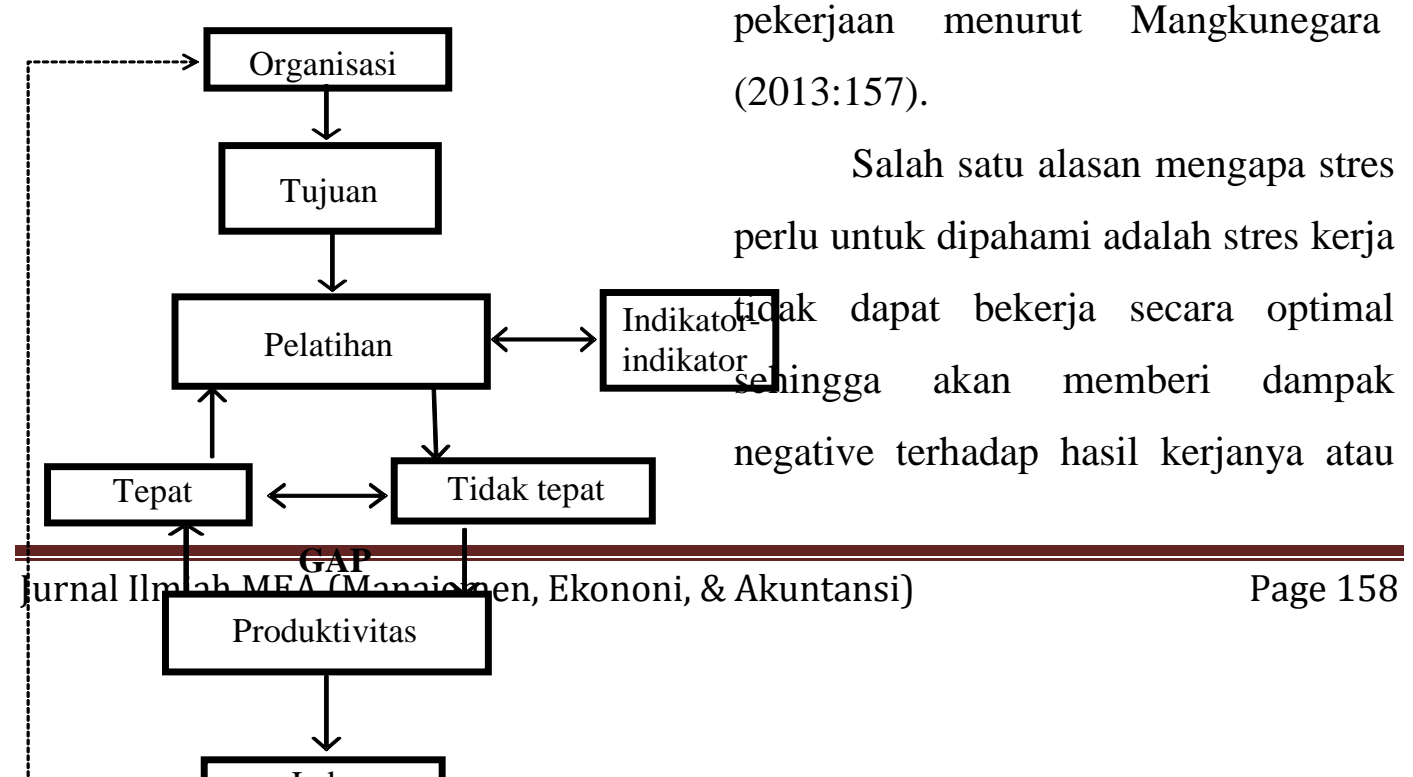

\section{Gambar 2. Diagram Tujuan Pelatihan}

\section{Stres Kerja}

Menurut Wijono (2010:122) stres adalah suatu kondisi dari hasil penghayatan subjektif individu dan lingkungan kerja yang dapat mengancam dan memberi tekanan secara psikologis, fisiologis dan sikap individu.

Gibson, dkk (2011:339) mendefinisikan stress kerja adalah suatu tanggapan penyesuaian diperantai oleh perbedaan perbedaan individu atau proses-proses psikologis, akibat dari setiap tindakan lingkaran, situasi atau peristiwa yang menetapkan permintaan psikologi ada fisik berlebihan kepada seseorang. Demikian juga pengertian stres kerja adalah perasaan tertekan yang dialami karyawan dalam menghadapi pekerjaan menurut Mangkunegara $(2013: 157)$

Salah satu alasan mengapa stres 
kata lain karyawan tidak dapat mengoptimalkan hasil kerjanya karyawan yang mengalami stres dapat mempengaruhi kemampuan karyawan tersebut (Faliza, 2011).

Indikator stres kerja menurut Mangkunegara (2013:157) diantaranya : a) Emosi yang tidak stabil; b) Perasaan tidak tenang; c) Sulit tidur; d) Merokok berlebihan; e) Tekanan darah meningkat; f) Mengalami gangguan pencernaan.

Penyebab stres kerja, antara lain beban kerja yang dirasakan terlalu berat, waktu kerja yang mendesak, kualitas pengawasan yang rendah, iklim kerja yang tidak sehat, otoritas kerja yang tidak memadai yang berhubungan dengan tanggung jawab, konflik kerja, perbedaan nilai antara karyawan dengan pemimpin yang frustasi dalam kerja.

Terdapat 3 pola dalam mengatasi stres yaitu:

1. Pola Sehat, adalah pola mengahadapi stres yang terbaik yaitu dengan kemampuan mengelola perilaku dan tindakan sehingga adanya stress tidak dapat menimbulkan gangguan, akan tetapi menjadi lebih sehat dan berkembang. Mereka yang tergolong kelompok ini biasanya mampu mengelola waktu dan kesibukan dengan cara yang baik.

2. Pola Harmonis, adalah pola menghadapi stres dengan kemampuan mengelola waktu dan kegaitan secara harmonis dan tidak menimbulkan berbagai hambatan. Dalam pola ini individu mampu mengendalikan kesibukan dan tantangan dengancara mengatur waktu secara teratur sehingga terjadi keharmonisan dan keseimbangan antara tekanan dan reaksi yang diberikan.

3. Pola Patologis, adalah pola menghadapi stres dengan berdampak berbagai gangguan fisik maupun sosial-psikologis. Dalam pola ini, individu akan menghadapi berbagai tantangan dengan caracara yang tidak dimiliki kemampuan dan keteraturan mengelola tugas dan waktu. Cara ini sangat berbahaya karena akan menimbulkan berbagai masalahmasalah yang buruk.

Untuk menghadapi stres dengan cara-cara yang sehat atau harmonis, dapat dilakukan dengan tiga cara : a) Memperkecil dan mengendalikan sumber-sumber stres; 
b) Menetralisir dampak yang ditimbulkan dari stres; Meningkatkan daya pribadi.

Dalam menghadapi semua nilai-nilai agama dalam bentuk keimanan dan ketaqwaan kepada Tuhan Yang Maha Esa merupakan pondasi utama, kecil kemungkinan memperoleh dampak negative dari stres.

\section{Produktivitas Kerja}

Sasaran utama manajemen sumber daya manusia adalah menciptakan system pemberdayaan personil yang dapat menampilkan produktivitas yang tinggi. Produktivitas kerja menunjukkan tingkat kemampuan pegawai dalam mencapai hasil (output), terutama dilihat dari sisi kuantitasnya. Oleh karena itu tingkat produktivitas setiap karyawan bisa berbeda, bisa tinggi atau bisa rendah, bergantung pada tingkat kegigihan dalam menjalankan tugasnya.

Dengan demikian, produktivitas kerja dapat diartikan sebagai hasil konkrit (produk) yang dihasilkan oleh individu atau kelompok, selama satuan waktu tertentu dalam suatu proses kerja (
Yuniarsih 2013 : 156 ) . Semakin c) tinggi produk dihasilkan dalam waktu singkat dapat dikatakan produktivitas kerja mempunyai nilai yang tinggi. Produktivitas dapat diartikan sebagai ratio antara hasil karya nyata (output) dalam bentuk barang dan jasa, dengan masukan (input) yang sebenarnya.

Greeberg dalam Muchdarsyah (2014:12) mendefinisikan produktivitas sebagai "perbandingan antar totalitas pengeluaran pada waktu tertentu dibagi totalitas masukan selama periode tersebut. Jadi produktivitas merujuk pada efektivitas dan efisiensi dalam memproduksi barang dan jasa.

Dalam berbagai referensi terdapat banyak sekali pengertian mengenai Produktivitas, yang dapat kita kelompokkan menjadi tiga, yaitu : a) Rumusan tradisional bagi keseluruhan Produktivitas tidak lain ialah ratio daripada apa yang dihasilkan (output) terhadap keseluruhan peralatan produksi yang dipergunakan (input); b) Produktivitas pada dasarnya adalah suatu sikap mental yang selalu mempunyai pandangan bahwa mutu kehidupan hari ini lebih baik dari hari kemarin, dan hari esok harus lebih baik 
daripada hari ini; c) Produktivitas merupakan interaksi terpadu secara serasi dari tiga faktor yakni investasi termasuk penggunaan pengetahuan dan teknologi serta riset, manajemen, dan tenaga kerja menurut (Muchdarsyah, 2014:16).

Menurut Sutrisno (2016:84) indikator produktivitas kerja : a. Kemampuan; b. Meningkatkan hasil yang dicapai; c. Semangat kerja; d. Pengembangan diri; e. Mutu; f. Efisiensi.

\section{Menurut Muchdarsyah} (2014:56) faktor-faktor yang mempengaruhi produktivitas yang umum yakni : a) Manusia; b) Modal; c) Metode/Proses; d) Lingkungan organisasi (Internal); e) Produksi; f) Lingkungan negara (Eksternal); g) Lingkungan Internasional maupun regional; h) Umpan balik.

Produktivitas kerja dapat diukur dengan dua standar utama yaitu produktivitas fisik dan produktivitas nilai. Secara fisik produktivitas diukur secara kuantitatif seperti banyaknya pengeluaran (panjang, berat, lamanya waktu, jumlah). Sedangkan berdasarkan nilai, produktivitas diukur atas dasar-dasar kemampuan, sikap, perilaku, disiplin, motivasi dan komitment terhadap tugas.
Produktivitas diukur dengan membandingkan output dengan input sesuai dengan persamaan berikut :

Indeks Produktivitas $=\frac{\text { Output }}{\text { alokasi Sumber }}$

$=\frac{\text { Performance }}{\text { Input }}=\frac{\text { Efektivitas }}{\text { Efisiensi }}$

Pengukuran produktivitas

kerja merupakan suatu proses sangat penting karena akan menjadi landasan dalam pembuatan kebijakan oleh manajemen. Diantaranya ada beberapa kondisi dalam pengukuran produktivitas kerja : a) Pengukuran harus berawal dari program perbaikan produktivitas; b) Pengukuran produktivitas dilakukan seharusnya melibatkan semua individu yang terlibat dalam proses industry; c) Pengukuran produktivitas dilakukan pada system industry secara keseluruhan; d) Pengukuran produktivitas seharusnya memunculkan data.

\section{Hipotesis Penelitian}

Untuk menguji hipotesis yang telah diajukan yaitu :

H1 : Terdapat Pengaruh Pelatihan Kerja Terhadap Produktvitas Kerja Karyawan

H2 : Terdapat Pengaruh Stres Kerja Terhadap Produktivitas Kerja 


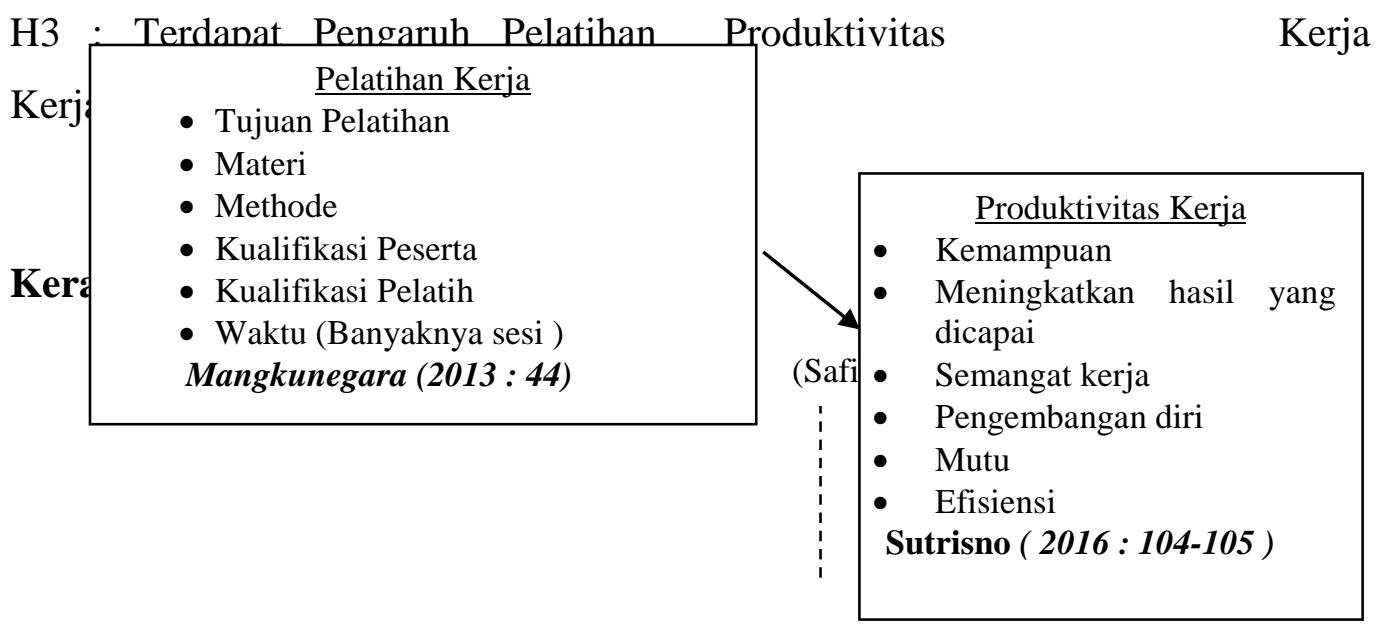

Stres Kerja

- Emosi yang tidak stabil

- Perasaan tidak tenang

- Sulit tidur

- Merokok berlebihan

- Tekanan darah meningkat

- Mengalami gangguan pencernaan

Mangkunegara (2013:157)

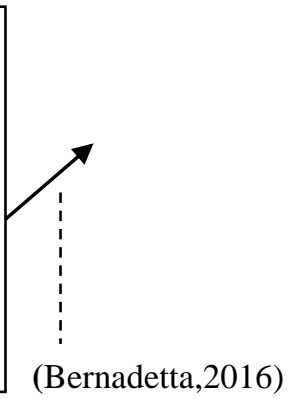

Gambar 3. Kerangka Pemikiran

\section{METODE PENELITIAN}

Metode yang digunakan dalam penelitian ini adalah metode deskriptif dan verifikatif dengan pendekatan kuantitatif, dimana akan mengetahui hubungan yang signifikan antara variabel yang diteliti sehingga kesimpulan yang akan memperjelas gambaran mengenai objek yang diteliti. Dengan menggunakan pendekatan Slovin dapat ditentukan sampel yang akan diambil 74 karyawan dari seluruh populasi karyawan di Bagian Produksi Departemen R-PET.
Pemberian Definisi konsep disini adalah untuk membantu memperjelas pengamatan yang akan diteliti sebagai berikut :

a. Pelatihan adalah suatu proses pendidikan jangka pendek yang menggunakan prosedur sistematis dan terorganisir dimana pegawai non manajerial mempelajari pengetahuan dan keterampilan teknis dalam tujuan terbatas. (Mangkunegara. 2013:44).

b. Stres Kerja adalah perasaan tertekan yang dialami karyawan dalam 
menghadapi

pekerjaan.

(Mangkunegara, 2013:157).

Produktivitas adalah sebagai

perbandingan antara hasil keluaran dan

masukan (Sutrisno, 2016:84)

jumlahnya 90 orang.

Guna mendapatkan data yang

diperlukan di dalam penelitian, maka

diperlukan beberapa teknik pengumpulan data, antara lain:

1. Penelitian

Kepustakaan

(Library Research) adalah

pengumpulan data sekunder yang

mendukung penelitian yang diperoleh dengan menggunakan penggalian dari berbagai literatur dan dokumen sebagai bahan dasar teori dalam membahas permasalahan yang sedang dialami.

2. Penelitian Lapangan (field Research) adalah pengumpulan data primer pada objek yang diteliti untuk memperoleh data yang diperlukan melalui :

a. Wawancara (interview), merupakan sebuah dialog yang akan dilakukan peneliti untuk mendapatkan info dari pihak terwawancara meliputi pimpinan perusahaan dan karyawan.

b. Observasi, dilakukan dengan cara mengamati secara langsung terhadap objek penelitian yang berkenaan dengan MSDM guna mendapatkan gambaran mengenai permasalahan yang sedang dihadapi. Dengan demikian dapat diketahui keadaan perusahaan yang sebenarnya c. Kuesioner (pertanyaan tertulis)

Kuesioner merupakan teknik pengumpulan data yang dilakukan dengan cara memberi seperangkat pertanyaan-pertanyaan tertulis kepada responden untuk dijawabnya. Untuk menguji tingkat validitas instrument dalam penelitian ini akan digunakan teknik analisis korelasi Product moment Pearson dengan rumus sebagai berikut : (Sugiyono, 2013:248). Untuk menguji validitas kuesioner, maka langkah selanjutnya adalah melakukan pengujian reliabilitas. "Reliabilitas (kehandalan) adalah instrumen yang bila digunakan beberapa kali untuk mengukur objek yang sama, akan menghasilkan data yang sama" (Sugiyono, 2013:173).

Teknik analisis data yang digunakan penulis adalah analisis data kuantitatif dengan bantuan statistik. Karena data yang dimiliki telah ditransformasikan dari data ordinal menjadi data interval, maka hipotesis yang digunakan penulis akan diuji dengan menggunakan teknik 
analisis koefisien korelasi product moment, regresi berganda, dan koefisien determinasi.

Dalam penelitian ini penulis menggunakan teknik analis data regresi berganda. Analisis regresi berganda digunakan untuk meramalkan bagaimana keadaan ( naik turunnya ) variabel dependen, bila dua atau lebih variabel independen sebagai faktor prediktor dimanupulasi (dinaik turunkan nilainnya).

Koefisien determinasi $\left(\mathrm{R}^{2}\right)$ pada intinya mengukur seberapa jauh kemampuan model daalam menerangkan variasi variabel dependent. Nilai koefisien determinasi adalah diantara nol dan satu. Nilai $\left(\mathrm{R}^{2}\right)$ yang kecil berarti kemampuan variabel-variabel independent dalam menjelaskan variasi variabel dependent memberikan hampir semua informasi yang dibutuhkan untuk memprediksi variasi variabel dependent (Imam, 2013 :45).

Dimana analisis koefisien determinasi ini adalah untuk mengetahui besarnya pengaruh variabel independent terhadap variabel dependent. Secara verbal $\mathrm{R}^{2}$ digunakan untuk mengukur proporsi atau presentasi variasi total dalam variabel dependent (Y) yang dijelaskan oleh variabel independent (X).

Uji Asumsi Klasik adalah pengujian data dalam penelitian skripsi untuk mengetahui kondisi yang di gunakan dalam suatu penelitian. Salah satunya adalah dengan cara uji normalitas. Jadi tujuan dari uji asumsi klasik adalah untuk mengetahui model analisis yang tepat dalam penelitian.

\section{Uji Multikolonieritas}

Bertujuan untuk menguji apakah pada model regresi ditemukan adanya korelasi antar variabel independen. Jika terjadi korelasi maka terdapat problem multikolonieritas pelaksanaannya dengan memakai matriks korelasi. Bila nilai matrik korelasi $\leq 0,5$ maka data terlepas dari gejala mulitikolonieritas. Kemudian apabila nilai VIF berada dibawah 10 dan nilai tolerace lebih hari 0,1 maka diambil kesimpulan bahwa model regresi tersebut tidak terdapat problem multikolonieritas (Ghozali 2006).

\section{Uji Heteroskedastisitas}

Bertujuan untuk menguji apakah dalam sebuah model regresi terjadi ketidaksamaan varians dari 
residual dari satu pengamatankepengamatan yang lain. Jika varians dari residual dari satu pengamatan-kepengamatan yang lain tetap disebut homokedastisitas dan kebalikannya heteroskesdasitas. Model regresi yang baik adalah homoskesdasitas.

Salah satu cara mendeteksi adanya heteroskesdastisitas adalah dengan melihat gafik plot antara nilai prediksi variabel terikat (dependen) yaitu ZPERD dan nilai nilai residualnya SRESID.

\section{Uji Normalitas}

Uji normalitas data bertujuan untuk menguji apakah dalam model regresi, variabel residual memiliki distribusi normal. Dimana untuk menguji apakah datadata yang dikumpulkan berdistribusi normal atau tidak dapat dilakukan metode sebagai berikut ini : Uji statistic sederhana yang sering digunakan untuk menguji asumsi normalitas adalah dengan menggunakan uji normalitas dari Kolmogorov Smirnov. Metode pengujian normal atau tidaknya distribusi data dilakukan dengan melihat nilai signifikan variabel jika signifikan lebih besar dari $\alpha=5 \%$ maka menunjukkan distribusi data normal.

Jadi uji normalitas adalah uji suatu data untuk mengetahui distribusinya normal atau tidak dengan menggunakan Kolmogorof Smirnov.

\section{Uji Autokorelasi}

Uji

autokorelasi

menggunakan uji Durbin-Watson Test(DW), dimaksudkan untuk menguji adanya kesalahan pengganggu periode 1 dengan kesalahan pengganggu periode sebelumnya -1 . Keadaan tersebut mengakibatkan pengaruh terhadap variabel dependen tidak hanya karena variabel independen namun juga variabel dependen periode lalu.

\section{Linearitas}

Uji terhadap linearitas berguna untuk mengetahui kebenaran bentuk model empiris yang digunakan dan menguji variabel yang relevan untuk dimasukan dalam model empiris yang bermanfaat untuk mengetahui adanya kesalahan dalam spesifikasi model. Uji linear yang digunakan adalah Ramsey, dimana kriterianya bila probabilitas $\mathrm{F}$ hitung $>\alpha$ (5\%), maka spesifikasi model sudah benar.

ANALISIS DATA DAN

PEMBAHASAN 


\section{Profil Responden}

Dalam peneliitan ini berdasarkan penyebaran kuesioner terhadap 74 orang karyawan diperoleh gambaran identitas responden berdasarkan usia, jenis kelamin, tingkat pendidikan Karyawan Bagian Produksi Departemen R-PET PT. Namasindo Plas Bandung Barat sebagai berikut : 1) usia responden yang paling banyak adalah pria dengan presentase $81,1 \%$ dibandingkan dengan responden wanita; 2) responden dengan usia 3140 berjumlah 24 orang atau 32,4\%, lebih banyak dari responden lainnya hal ini karena pada saat kuisioner ini disebar kebetulan yang paling banyak usia 31-40 tahun; 3) responden yang memiliki pendidikan SMA/Sederajat paling banyak dengan presentase $44,2 \%$ dibandingkan dari pendidikan lainnya.

\section{Uji Validitas dan Reliabilitas}

Berdasarkan hasil uji validitas, diketahui bahwa semua item pertanyaan valid dengan nilai r-hiung di atas nilai r-kritic $(0,300)$, sehingga
49 pernyataan pada kuesioner dalam penelitian ini layak untuk diikutsertakan dalam penelitian ini.

Tabel 7. Hasil Pengujian Reliabilitas

\begin{tabular}{|c|c|c|c|}
\hline Variabel & Reliabilitas & r Kritis & Keterangan \\
\hline $\mathrm{X} 1$ & 0,786 & 0,700 & Reliabel \\
\hline $\mathrm{X} 2$ & 0,883 & 0,700 & Reliabel \\
\hline $\mathrm{Y}$ & 0,810 & 0,700 & Reliabel \\
\hline
\end{tabular}

Sumber : data diolah, 2018

Berdasarkan hasil pengujian reliabilitas semua variabel mempunyai reliabilitas yang baik karena memiliki $\mathrm{r}$ hitung yang lebih besar dari $\mathrm{r}$ Kritis seperti terlihat pada tabel di atas, dengan demikian, setiap pernyataan pada kuisioner tersebut dapat dianalisa lebih lanjut.

Tabel 8. Rekapitulasi Variabel Pelatihan Kerja

\begin{tabular}{|c|l|c|c|c|}
\hline $\begin{array}{r}\mathbf{N} \\
\mathbf{o}\end{array}$ & Indikator & $\begin{array}{c}\text { Rata- } \\
\text { rata }\end{array}$ & $\begin{array}{c}\text { Persen } \\
\text { tase }\end{array}$ & $\begin{array}{c}\text { Kateg } \\
\text { ori }\end{array}$ \\
\hline 1 & $\begin{array}{l}\text { Tujuan dan } \\
\text { Sasaran }\end{array}$ & 3.69 & $16 \%$ & $\begin{array}{c}\text { Tingg } \\
\text { i }\end{array}$ \\
\hline 2 & Materi & 3.95 & $17,1 \%$ & Tinggi \\
\hline 3 & $\begin{array}{l}\text { Methode yang } \\
\text { digunakan }\end{array}$ & 4.04 & $17,5 \%$ & Tinggi \\
\hline 4 & $\begin{array}{l}\text { Kualifikasi } \\
\text { Peserta }\end{array}$ & 4.12 & $17,8 \%$ & Tinggi \\
\hline 5 & $\begin{array}{l}\text { Kualifikasi } \\
\text { pelatih }\end{array}$ & 3.60 & $15,6 \%$ & Tinggi \\
\hline \multirow{2}{*}{6} & $\begin{array}{l}\text { Waktu } \\
\text { (banyak sesi) }\end{array}$ & 3.73 & 16,1 & Tinggi \\
\cline { 1 - 3 } & Jumlah & $\mathbf{2 3 . 1 0}$ & $\mathbf{1 0 0}$ & Tinggi \\
\cline { 2 - 3 } & Rata-rata & $\mathbf{3 , 8 6}$ & $\%$ & \\
\hline
\end{tabular}

Sumber: hasil kuisioner diolah,2018

Tabel 9. Rekapitulasi Variabel Stress Kerja

\begin{tabular}{|l|l|c|c|c|}
\hline No. & Indikator & Rata-rata & Persentase & Kategori \\
\hline 1 & Emosi yang tidak stabil & 3.72 & $16.3 \%$ & Tinggi \\
\hline
\end{tabular}




\begin{tabular}{|l|l|c|c|c|}
\hline 2 & Perasaan tidak tenang & 3.89 & $17.1 \%$ & Tinggi \\
\hline 3 & Sulit tidur & 3.96 & $17.4 \%$ & Tinggi \\
\hline 4 & Merokok yang berlebihan & 3.74 & $16.4 \%$ & Tinggi \\
\hline 5 & Tekanan darah meningkat & 3.85 & $16.9 \%$ & Tinggi \\
\hline 6 & Mengalami gangguan pencernaan & 3.64 & $15.9 \%$ & Tinggi \\
\hline \multirow{2yynn}{*yynn}{} & Jumlah & $\mathbf{2 2 . 8}$ & $\mathbf{1 0 0 \%}$ & Tinggi \\
\cline { 2 - 3 } & Rata-rata & $\mathbf{3 , 8 0}$ & & \\
\hline
\end{tabular}

Sumber: hasil kuisioner diolah,2018

Tabel 10. Rekapitulasi Variabel Produktivitas Kerja

\begin{tabular}{|c|l|c|c|c|}
\hline No. & \multicolumn{1}{|c|}{ Indikator } & Rata-rata & Persentase & Kategori \\
\hline 1 & Kemampuan & 1.94 & $15.6 \%$ & Rendah \\
\hline 2 & Meningkatkan hasil yang dicapai & 2.33 & $18.6 \%$ & Rendah \\
\hline 3 & Semangat kerja & 2.32 & $18.6 \%$ & Rendah \\
\hline 4 & Pengembangan diri & 2.12 & $17.1 \%$ & Rendah \\
\hline 5 & Mutu & 1.82 & $14.6 \%$ & Rendah \\
\hline 6 & Efisiensi & 1.93 & $15.5 \%$ & Rendah \\
\hline \multirow{2}{*yyyn}{} & Jumlah & $\mathbf{1 2 . 4 6}$ & $\mathbf{1 0 0 \%}$ & Rendah \\
\cline { 2 - 5 } & Rata-rata & $\mathbf{2 , 0 7}$ & & \\
\hline
\end{tabular}

Sumber: hasil kuisioner diolah,2018

Tabel 11. Deskriptif Statistik

\begin{tabular}{|c|c|c|}
\hline Variabel & Responden & $\begin{array}{c}\text { Rata- } \\
\text { Rata }\end{array}$ \\
\hline Pelatihan & 74 & 3,86 \\
Stress Kerja & 74 & 3,80 \\
Produktivitas & 74 & 2,07 \\
Kerja & 74 & \\
Valid N & & \\
(listwise) & & \\
\hline
\end{tabular}

Sumber : Hasil Perhitungan SPSS 17

Dari tabel diatas menunjukkan skor rata-rata variable produktivitas kerja lebih tinggi bila dibandingkan dengan variable lainnya. Untuk memberikan gambaran yang lebih jelas mengenai makna hasil perhitungan statistik deskriptif diatas, selanjutnya dibandingkan dengan tabel kriteria penafsiran kondisi variable penelitian pada masingmasing variable yang diteliti. Model yang dipakai mengadopsi model pengontrolan kualitas dari (Suprapto,2001)

Berdasarkan hasil perhitungan deskriptif dibandingkan dengan kriteria diatas, maka diperoleh hasil sebagai berikut ;

Tabel 9. Kriteria penafsiran kondisi variabel penelitian 


\begin{tabular}{|l|c|c|}
\hline \multicolumn{1}{|c|}{ Variabel } & $\begin{array}{c}\text { Rata- } \\
\text { rata }\end{array}$ & Kriteria \\
\hline Pelatihan & 3,86 & Tinggi \\
\hline Stress Kerja & 3,80 & Tinggi \\
\hline Produktivitas & 2,07 & Rendah \\
\hline
\end{tabular}

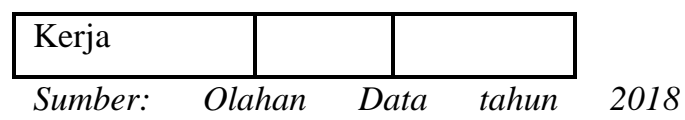

\section{Analisis Verifikatif Uji Normalitas}
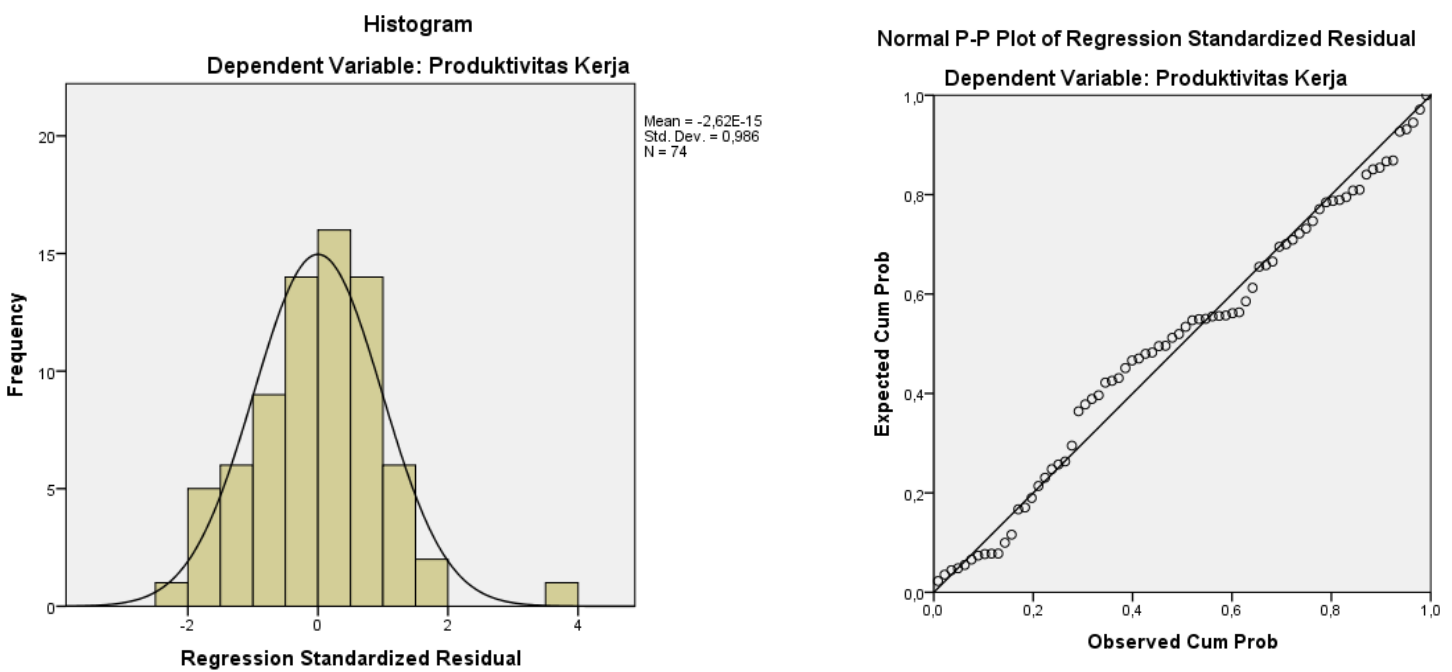

Dengan melihat tampilan grafik

\section{UJI MULTIKOLINIERITAS}

histogram, terlihat bahwa kurva dependent dan regression standardized residual membentuk gambar seperti lonceng. Oleh karena itu maka dapat disimpulkan bahwa data yang digunakan merupakan data yang terdistribusi secara normal. Kemudian pada grafik normal P-Plot terlihat bahwa titik-titik menyebar disekitar garis diagonal yang juga mengindikasikan bahwa data yang digunakan merupakan data yang terdistribusi secara normal, sehingga analisis regresi layak digunakan.

\begin{tabular}{|l|l|l|}
\hline \multirow{2}{*}{ Model } & \multicolumn{2}{|c|}{$\begin{array}{c}\text { Collinearity } \\
\text { Statistics }\end{array}$} \\
\cline { 2 - 3 } & Tolerance & VIF \\
\hline 1 (Constant) & & \\
Pelatihan & \multirow{2}{*}{$\begin{array}{l}\text { Kerja } \\
\text { Stres } \\
\text { Kerja }\end{array}$} & 1,853 \\
\hline
\end{tabular}

Untuk melakukan uji multikolinieritas dalam penelitian ini digunakan uji Multikolinieritas dengan TOL (Tolerance) dan Variance Inflation Factor (VIF). Jika nilai VIF tidak lebih dari 10, maka model 
dinyatakan terbebas dari gejala multikolinier.

Dari tabel Coefficients di atas, dapat dilihat bahwa nilai VIF (Variance Inflation Factor) masingmasing variabel independen adalah sebesar 1,853, yang berarti lebih kecil dari 10, sehingga dapat disimpulkan bahwa model regresi yang terbentuk terbebas dari masalah multikolinieritas.

\section{UJI HETEROSKESDASTISITAS}

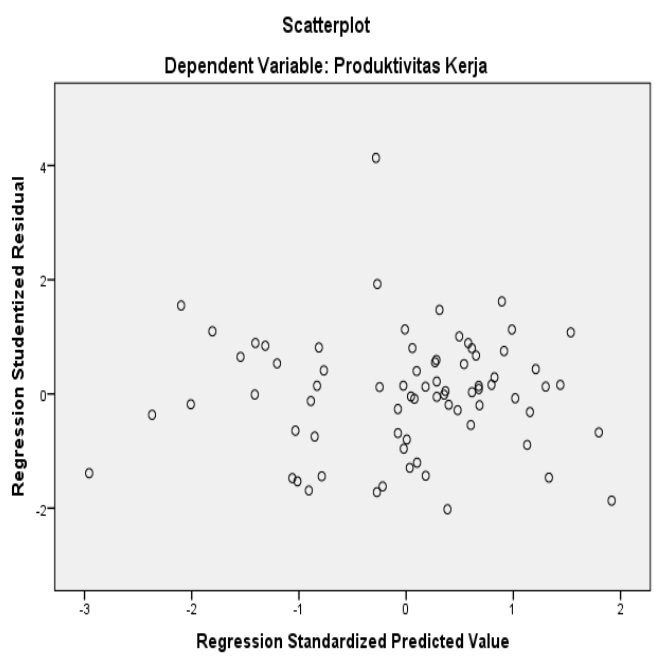

Dari grafik scatter plot terlihat bahwa titik-titik menyebar secara acak serta tersebar baik di atas maupun di bawah angka 0 pada sumbu Y. dengan demikian dapat disimpulkan bahwa model regresi yang terbentuk tidak mengalami masalah heteroskedastisitas.

\section{ANALISA REGRESI BERGANDA}

\begin{tabular}{|c|c|c|c|c|c|c|}
\hline & \multirow[t]{2}{*}{ Model } & \multicolumn{2}{|c|}{ Unstandardized Coefficients } & $\begin{array}{l}\text { Standardized } \\
\text { Coefficients }\end{array}$ & \multirow[t]{2}{*}{$\mathrm{T}$} & \multirow[t]{2}{*}{ Sig. } \\
\hline & & $\mathrm{B}$ & Std. Error & Beta & & \\
\hline \multirow{3}{*}{1} & (Constant) & $-14,517$ & 3,138 & & $-4,626$ & ,000 \\
\hline & Pelatihan Kerja & 1,389 &, 098 & ,797 & 14,127 & ,000 \\
\hline & Stres Kerja &, 312 & ,092 & ,191 & 3,383 & ,001 \\
\hline
\end{tabular}

Dari tabel diatas dapat diperoleh:

1. t hitung untuk Pelatihan Kerja sebesar 14,127

2. $\mathrm{t}$ hitung untuk Stres Kerja sebesar 3,383
Lalu langkah selanjutnya adalah menentukan daerah penerimaan dan penolakan $\mathrm{H}_{0}$ dengan membandingkan antara $\mathrm{t}$ hitung dengan t tabel. Adapun kriteria yang 
digunakan untuk menentukan daerah penerimaan dan penolakan $\mathrm{H}_{0}$ adalah :

$\mathrm{H}_{0}$ ditolak bila $\quad \mathrm{t}$ hitung $>\mathrm{t}$ tabel atau -t hitung <-t tabel

$\mathrm{H}_{0}$ diterima bila : $-\mathrm{t}$ tabel $\leq \mathrm{t}$ hitung $\leq \mathrm{t}$ table degree of freedom $(d f) \quad$ : a) n-k-1 $=74-2-1=71 ; \mathrm{n}=$ jumlah observasi $; \mathrm{k}$ $=$ jumlah variabel tidak termasuk konstanta; b) $\alpha=0,05$; c) Uji dua pihak

Persamaan Regresi tersebut dapat dijelaskan sebagai berikut :

Berdasarkan daftar nilai $\mathrm{t}$ tabel, $\mathrm{df}=$ 71, dengan tingkat signifikansi 0,05 akan diperoleh t tabel sebesar 1,853. Nilai $\mathrm{t}$ hitung pada hasil koefisien regresi menunjukan bahwa :

3. Variabel Pelatihan Kerja : t hitung > t tabel pada tingkat signifikansi 5\% adalah 14,127 > 1,853 sehingga Ho ditolak.

4. Variabel Stres Kerja : $\mathrm{t}$ hitung $>\mathrm{t}$ tabel pada tingkat signifikansi 5\% adalah 3,383>1,853 sehingga Ho ditolak.

Hal ini diperkuat dengan nilai Sig. Untuk masing-masing variabel dimana: 1. Variabel X1-Y : Sig $>\alpha(0,000<0,05)$ 2. Variabel $X 2-Y: \operatorname{Sig}>\alpha(0,000<0,05)$ Dari uji hipotesis yang dilakukan, maka dapat ditarik kesimpulan :

1.Dengan tingkat signifikansi 0,05 Pelatihan kerja karyawan mempunyai pengaruh yang signifikan terhadap Produktifitas.

2. Dengan tingkat signifikansi 0,05 Stres kerja karyawan mempunyai pengaruh yang signifikan terhadap Produktifitas Kerja. 3.

ANALISIS KORELASI PARSIAL

\begin{tabular}{|c|c|c|c|c|c|c|c|c|c|}
\hline \multirow{2}{*}{ Model } & \multicolumn{2}{|c|}{$\begin{array}{l}\text { Unstandard } \\
\text { ized } \\
\text { Coefficient } \\
\text { s } \\
\end{array}$} & $\begin{array}{l}\text { Standardize } \\
\text { Coefficient }\end{array}$ & \multirow{2}{*}{$\mathrm{t}$} & \multirow{2}{*}{ Sig. } & \multicolumn{4}{|c|}{ Correlations } \\
\hline & B & $\begin{array}{l}\text { Std. } \\
\text { Erro } \\
\mathrm{r}\end{array}$ & Beta & & & $\begin{array}{l}\text { Zero- } \\
\text { order }\end{array}$ & $\begin{array}{c}\text { Parti } \\
\text { al }\end{array}$ & Part & \\
\hline $\begin{array}{l}\text { (Constant) } \\
\text { Pelatihan }\end{array}$ & \multicolumn{2}{|c|}{$-14,517$} & 3,138 & & $-4,626$ & $\begin{array}{l}, 00 \\
0\end{array}$ & & & \\
\hline Kerja & \multirow{2}{*}{\multicolumn{2}{|c|}{1,389}} & 098 & ,79 & 14,12 & , 00 &, 92 &, 85 & ,58 \\
\hline Stres & & & & 7 & & 0 & 7 & 9 & 5 \\
\hline Kerja & \multicolumn{2}{|c|}{, 312} &, 092 & $\begin{array}{l}19 \\
1\end{array}$ & 3,383 & $\begin{array}{l}00 \\
1\end{array}$ & $\begin{array}{l}, 73 \\
2\end{array}$ & $\begin{array}{l}37 \\
3\end{array}$ & $\begin{array}{l}, 14 \\
0\end{array}$ \\
\hline
\end{tabular}


Uji korelasi bertujuan untuk menguji hubungan antara dua variabel yang tidak menunjukan hubungan fungsional. Berdasarkan tabel di atas dapat ditarik kesimpulan sebagai berikut:

Pelatihan kerja $\rightarrow$ Produktivitas kerja $=$ $(0,797 \times 0,927=0,74$ atau $74 \%)$

Stres kerja $\rightarrow$ Produktivitas kerja $=$ $(0,191 \times 0,732=0,14$ atau $14 \%)$

4. Hubungan atau korelasi antara Pelatihan Kerja $\left(\mathrm{X}_{1}\right)$ dengan Produktivitas Kerja (Y) adalah sebesar $74 \%$ yang berarti korelasi kuat. Arah hubungan korelasi yang ada adalah arah hubungan positif yang berarti pada saat Pelatihan Kerja $\left(\mathrm{X}_{1}\right)$ mengalami kenaikan, maka Produktivitas Kerja (Y) akan mengalami kenaikan dan sebaliknya. Nilai signifikasi yang ada adalah $0,000<0,05$ yang berarti korelasi yang ada adalah korelasi yang signifikan. Pelatihan Kerja yang baik tentu berkaitan dengan bagaimana memberdayakan karyawan dengan baik yang efeknya pada kualitas SDM sehingga sangat wajar bila kedua variabel ini memiliki hubungan yang positif serta signifikan.

5. Hubungan atau korelasi antara Stres Kerja $\left(\mathrm{X}_{2}\right)$ dengan Produktivitas Kerja (Y) adalah sebesar 14\% yang berarti korelasi lemah. Arah hubungan korelasi yang ada adalah arah hubungan positif yang berarti pada saat Stres Kerja $\left(\mathrm{X}_{2}\right)$ mengalami penurunan, maka Produktivitas Kerja (Y) akan mengalami kenaikan dan sebaliknya jika Stres Kerja $\left(\mathrm{X}_{2}\right)$ mengalami kenaikan, maka Produktivitas Kerja (Y) akan mengalami penurunan. Nilai signifikasi yang ada adalah $0,000<$ 0,05 yang berarti korelasi yang ada adalah korelasi yang signifikan. Karyawan yang mengalami stres dalam bekerja akan menurunkan tingkat produktivitas mereka yang sekaligus akan mengurangi tingkat produksi perusahaan secara keseluruhan sehingga sangat wajar apabila kedua variabel ini memiliki hubungan yang positif dan signifikan.

KOEFISIEN DETERMINASI $\left(\mathbf{R}^{2}\right)$

\begin{tabular}{|l|l|l|l|l|}
\hline Model & $\mathrm{R}$ & R Square & $\begin{array}{l}\text { Adjusted } \\
\text { R Square }\end{array}$ & $\begin{array}{l}\text { Std. Error of the } \\
\text { Estimate }\end{array}$ \\
\hline
\end{tabular}




\begin{tabular}{|l|l|l|l|l|}
\hline 1 &, $937^{\mathrm{a}}$ &, 878 &, 875 & 3,1813709 \\
\hline \multicolumn{3}{|c|}{ Berdasarkan tabel di atas dapat menjelaskan variabel dependen }
\end{tabular}

dilihat bahwa nilai Adjusted R-square (Produktivitas Kerja) adalah sebesar dari model regresi yang terbentuk $87,5 \%$ sisanya sebesar $12,5 \%$ dalam penelitian ini adalah sebesar dijelaskan oleh variabel lain yang tidak ,875 yang menunjukan bahwa dimasukan ke dalam model penelitian. kemampuan variabel independen dalam

PENGUJIAN SECARA SIMULTAN (Uji F)

\begin{tabular}{|ll|l|l|l|l|l|}
\hline \multicolumn{2}{|c|}{ Model } & $\begin{array}{l}\text { Sum } \\
\text { Squares }\end{array}$ & df & Mean Square & F & Sig. \\
\hline 1 & Regression & 5174,374 & 2 & 2587,187 & 255,623 &, $000^{\mathrm{b}}$ \\
& Residual & 718,600 & 71 & 10,121 & & \\
& Total & 5892,973 & 73 & & & \\
\hline
\end{tabular}

a. Dependent Variable: Produktivitas Kerja

b. Predictors: (Constant), Stres Kerja, Pelatihan Kerja

Dari hasil output regresi di atas, digunakan untuk memprediksi dapat dilihat bahwa secara simultan Produktivitas Kerja. Atau dapat variabel independen memiliki pengaruh dikatakan bahwa variabel Pelatihan yang signifikan terhadap variabel Kerja $\left(X_{1}\right)$, Stres Kerja $\left(X_{2}\right)$, secara dependen. Hal ini dapat dibuktikan dari simultan berpengaruh secara signifikan nilai F hitung sebesar 255,623 terhadap variabel Produktivitas Kerja sedangkan nilai $\mathrm{F}$ tabel adalah dengan $(\mathrm{Y})$.

df : $\alpha,(\mathrm{k}-1),(\mathrm{n}-\mathrm{k})$ atau df : 0,05 (3-1), (71-3) adalah 3.976 yang berarti bahwa $\mathrm{F}_{\text {hitung }}<\mathrm{F}_{\text {tabel. }}$. Hal ini juga dapat dilihat dengan besarnya nilai probabilitas 0,000 yang berarti lebih kecil dari pada tingkat signifikasi yang digunakan yaitu 0,05 atau $5 \%$, maka dapat disimpulkan bahwa model regresi dapat

\section{PENGUJIAN SECARA PARSIAL (UJI t)}

Uji $t$ yang dilakukan menggunakan uji dua sisi (two tail test), dengan $\alpha=5 \%$, maka diperoleh nilai $\mathrm{t}$ tabel sebagai berikut :

t-tabel (t-kritis) $=|\alpha ; \mathrm{df}=(\mathrm{n}-\mathrm{k}-1)|=$ $0,05,74-2-1=1.994$ 
Selain membandingkan nilai $\mathrm{t}$ tabel dengan $\mathrm{t}$ hitung, untuk mengetahui apakah variabel independen berpengaruh signifikan terhada variabel dependen dalam penelitian ini juga dilakukan dengan melihat nilai probabilitas masing-masing variabel independen. Apabila nilai probabilitas variabel independen lebih kecil dari tingkat signifikasi yang digunakan yaitu $5 \%$ atau 0,05 , maka dapat disimpulkan bahwa terdapat pengaruh signifikan variabel dependen terhadap variabel independen.

\begin{tabular}{|l|l|l|l|l|l|}
\hline \multirow{2}{*}{ Model } & \multicolumn{2}{l|l}{$\begin{array}{l}\text { Unstandardized } \\
\text { Coefficients }\end{array}$} & $\begin{array}{l}\text { Standardized } \\
\text { Coefficients }\end{array}$ & $\mathrm{t}$ & Sig. \\
\cline { 2 - 5 } & $\mathrm{B}$ & Std. Error & Beta & & \\
\hline 1 (Constant) & $-14,517$ & 3,138 & & $-4,626$ &, 000 \\
Pelatihan Kerja & 1,389 &, 098 &, 797 & 14,127 &, 000 \\
Stres Kerja &, 312 &, 092 &, 191 & 3,383 &, 001 \\
\hline
\end{tabular}

Berdasarkan tabel di atas, dapat diketahui uji parsial masing-masing variabel pada penelitian ini sebagai berikut :

1.Pengaruh Pelatihan Kerja $\left(\mathrm{X}_{1}\right)$ terhadap Produktivitas Kerja (Y), Nilai t hitung Pelatihan Kerja adalah 14,127 yang berarti lebih besar dari $t$ tabel 1.994 dengan nilai signifikasi 0,000 yang berarti lebih kecil dari tingkat signifikasi yang digunakan yaitu $0,05 \quad($ alpha $=5 \%)$, maka dengan demikian disimpulkan bahwa variabel Pelatihan Kerja berpengaruh positif signifikan terhadap variabel Produktivitas Kerja.
2. Pengaruh Stres Kerja $\left(X_{2}\right)$ terhadap Produktivitas Kerja (Y), Nilai t hitung Stres Kerja adalah 3,383 yang berarti lebih besar dari t tabel 1.994 dengan nilai signifikasi 0,000 yang berarti lebih kecil dari tingkat signifikasi yang digunakan yaitu 0,05 (alpha $=5 \%)$, maka dengan demikian disimpulkan bahwa variabel Stres Kerja berpengaruh positif signifikan terhadap variabel Produktivitas Kerja.

\section{SIMPULAN}

1. Berdasarkan paparan jawaban responden mengenai pelatihan di lingkungan Bagian Produksi Departemen R-PET PT.Namasindo Plas Bandung Barat diperoleh rata- 
rata jawaban responden sebesar 3,86 dengan kriteria baik namun masih terdapat pernyataan yang masih rendah yaitu pada indikator kualitas pelatih dan item pernyataan karyawan senang ketika pelatihan karena trainernya dapat membangkitkan Semangat seluruh pesertanya.

2. Berdasarkan paparan jawaban responden mengenai stress kerja Bagian Produksi Departemen RPET PT.Namasindo Plas Bandung Barat diperoleh rata-rata jawaban responden sebesar 3,80 dengan kriteria baik namun masih terdapat pernyataan yang masih tinggi yaitu indikator sulit tidur.

3. Berdasarkan paparan jawaban responden mengenai produktivitas kerja di Bagian Produksi Departemen R-PET PT.Namasindo Plas Bandung Barat diperoleh ratarata jawaban responden sebesar 2,07 dengan kriteria rendah namun masih terdapat pernyataan yang masih sangat tinggi yaitu saya selalu menjaga absensi dikarenakan tanggung jawab sebagai karyawan dengan skor rata-rata 2,90.

4. Pelatihan memiliki pengaruh yang signifikan artinya apabila jika pelatihan ditingkatkan maka variabel produktivitas kerja juga akan meningkat yaitu sebesar 74 $\%$.

5. Stress Kerja memiliki pengaruh yang signifikan artinya apabila stress kerja berkurang maka variabel produktivitas kerja akan meningkat yaitu sebesar $14 \%$.

6. Pelatihan dan stress kerja memberikan pengaruh sebesar $87,5 \%$ terhadap produktivitas kerja, angka $87,5 \%$ disini artinya setiap perubahan produktivitas kerja sebesar $87,5 \%$ dipengaruhi oleh perubahan variabel Pelatihan dan Stress Kerja. Adapun sisanya sebesar $12,5 \%$ disebabkan oleh variabel-variabel lain diluar kedua variabel tersebut yang tidak dilibatkan dalam penelitian ini, antara lain motivasi, imbalan. Dengan demikian bahwa variabel X1 ( Pelatihan Kerja ) dan variabel X2 ( Stres Kerja ) mengandung arti bahwa variabel X1 (Pelatihan Kerja) dan variabel X2 (Stres Kerja) akan berpengaruh terhadap variabel Y (Produktifitas Kerja) dengan kata lain akan meningkatnya Produktifitas Kerja Karyawan. 


\section{Saran}

1. Guna meningkatkan dimana karyawan senang ketika pelatihan karena trainernya dapat membangkitkan semangat seluruh pesertanya tentu dibarengi dengan kwalitas trainer dan efektifnya materi yang disampaikan sehingga tujuan bersama karyawan dan perusahaan tercapai.

2. Guna mengurangi masih ada karyawan yang sulit tidur perusahaan diharuskan memberikan evaluasi kinerja karyawan terhadap target dan kemampuan karyawan dan memberikan konseling psikologis kepada karyawan sehingga bisa mengurangi atau menghilangkan karyawan yang sulit tidur.

3. Guna meningkatkan kemampuan karyawan dalam menyelesaikan pekerjaan dengan cepat dan tepat sesuai target yang diberikan hendaknya perusahaan menetapkan target yang terukur dan realistis ditambah dengan memberikan pelatihan kerja yang disesuaikan kebutuhan karyawan dan target perusahaan.

4. Guna meningkatkan Produktivitas Kerja hendaknya perusahaan memperhatikan indikator indikator yang lemah dalam setiap variabel.

5. Guna meningkatkan Produktivitas Kerja hendaknya organisasi memperbaiki Produktivitas Kerja supaya bisa melayani Customer dengan optimal serta memperbaiki pengawasan yang ada diperusahaan.

6. Guna mengurangi pengaruh Stress Kerja terhadap Produktivitas Kerja maka, hendaknya perusahaan memberikan layanan yang akurat terhadap karyawan agar mudah dalam pengendaliannya.

\section{DAFTAR PUSTAKA}

Alek S. Nitisemito, 2006, Manajemen Personalia, Edisi kedua, Ghalia Indonesia

Anwar Prabu Mangkunegara.2010. Manajemen Sumber Daya Manusia Perusahaan. PT.Remaja Rosda Karya. Bandung.

Bernadin, H. Jhon.2013. Human Reseurce Mangement. MCGrewHill Companies, Inc. New York.

Byars, Lloyd L \& Rue, Leslie W.2010.Human Resource Management. The McGraw-hill. North America.

Cashway, Barry.2010. Human Researhes Manajemen. Elex media Komputindo. Jakarta.

Cowling dan James. 2010.Manajemen Personalia Dan Hubungan Industrial. Andi.

Djarkasih. 2010.Organisasi. Jakarta. 
Moch Sa'ad.2013. Psykologi Industri (seri Sumber daya Manusia). Edisi 4. PT. Liberty. Yogyakarta.

Martoyo, Susilo. 2007.Manajemen Sumber Daya Manusia, Edisi 5, Cetakan Pertama,BPFE Yogyakarta.

Malayu Hasibuan.2013. Manajemen Sumber Daya Manusia. PT.Bumi Aksara. Jakarta.

Mathis, Robert. L dan Jackson, Jhon. H.2010. Manajemen Sumber Daya Manusia Edisi 1 dan 2. Salemba. Jakarta.

Mutiara

Panggabean.2013.Manajemen

S.

Sumber Daya Manusia. Bogor. Ghalia Indonesia.

Rivaai, Veithza; Mohd. Basri, dato' Ahmad Fawji.2010. Performance Appraisal. PT. Raja Grafindo Persada. Jakarta.

Robbins, P. Stephen.2007 Organizational Behavior. Pearson Education, Inc. New Jersey.

Sjafri Mangkuprawira.2013. Manajemen Sumber Daya Manusia Strategik. Ghlia Indonesia. Jakarta.

Sedarmayanti.2010. Pengembangan Kepribadian Pegawai. Penerbit Mandar Maju. Bandung.

Sugiyono. 2013.Statistik Untuk Penelitian. Bandung. CV. Alfabeta. 2013. Metode Penelitian Bisnis. CV. Alfabeta. Bandung

Azhar Aulia.2012 Pengaruh Kompensasi dan Motivasi Terhadap Prestasi Kerja Karyawan di RS PT. Perkebunan Nusantra VIII (Persero).Tesis UNPAD. Bandung.

Yul Anggraeni.2012 Pengaruh Kompensasi Melalui Motivasi
Terhadap Kinerja karyawan Pada PT Jasindo Prima Sakti Kantor Cabang Bandung.. Bandung.

Ida Hasanah.2013 Pengaruh Komepnsasi Dan Motivasi Terhadap Kinerja Karyawan Pada PT. Bighta Tryphena Garmen Di Bandung. Univ Widyatama. Bandung

Ahmed, Umair.2010. A Bit Harsh On COEs. Extention Journal, Inc.

David, R. 2013.Jhoni. Jurnal Riset Ekomoni Dan Manajemen; Fact Model Untuk Pembinaan Motivasi Bagi Karyawan (Studi Kasus Motivasi Pada Usaha jasa Penerbangan Internasional Surabaya). ISEI. Surabaya.

Pranoto.2011 Pengaruh System Insentif Terhadap Produktivitas Karyawan Asuransi. Jurnal Manajemen dan Akuntansi.

Shahid, Muhammad Bilal.2010. Villains or Heros. Extention Journal, Inc.

Tatik Budiningsih.2015 Jurnal Manajemen; Pengaruh Seleksi Dan Kompensasi Terhadap Performansi Manajer Suatu Survei Pada Strategik Business Unit Di Kota Bandung. Maranatha.bandung.

Tri Sugiarti.2012. Jurnal Telaah Bisnis;Pentingnya Sistem GajiDan Insentive Reward Dalam Mendukung Strategi Bisnis. MP. YKPN. Yogyakarta.

Cerdas Kaban. 2007. Perbaikan Pelayanan Publik Meningkatkan Kinerja.. Jakarta

Minto Mulyono. 2015. Mengubah Keluhan Menjadi Pelayanan Yang Baik.. Jakarta 
Publisher: LPPM STIE Muhammadiyah Bandung

E-ISSN: 2621-5306 P-ISSN: 2541-5255

Vol. 2 No. 3 September - Desember 2018 